\title{
Beyond revenge?: Responsible Bible reading practices in a Traumatized Land
}

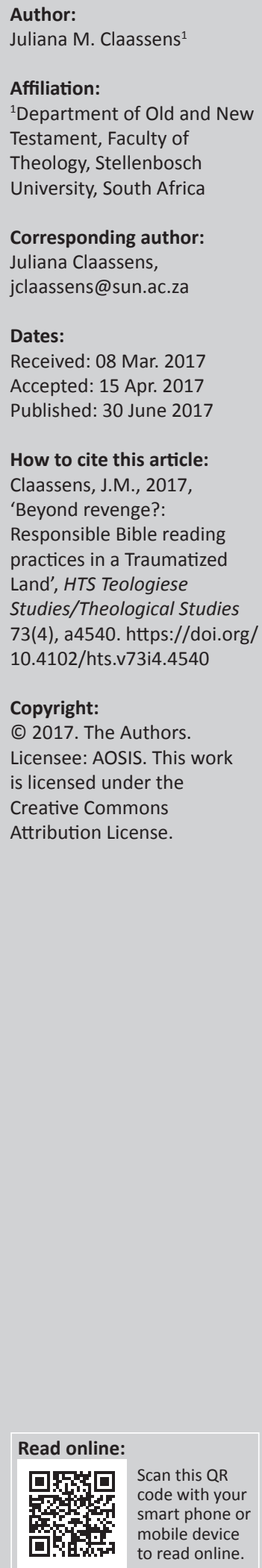

In this article, I argue that revenge fantasies such as those found in the Oracles Against the Nations (OAN) in Jeremiah 45-51 underscore the necessity for responsible Bible reading practices. I argue that to protect us from our own worst selves, the very human tendency to resort to revenge that inevitably leads to violence, one needs to read these biblical texts in terms of contemporary hermeneutical approaches that may play some role to bring an end to violence. A first such approach that serves as an important tool to help us understand these revenge fantasies as found in the OAN is the relatively new field of inquiry of trauma hermeneutics that is particularly helpful in order to mitigate the violent aspects of these revenge fantasies. Moreover, I propose that recent approaches such as feminist and postcolonial biblical interpretation are also vital for nurturing ethical, just communities that actively pursue justice.

\section{Sweet revenge?}

In one of the most spectacularly haunting movie scenes, on the outskirts of a small Australian Outback home town, Kate Winslet runs a bright red roll of satin material from her house right into the middle of the village and sets it light, resulting in the whole town going up in a blaze of fire. This final dramatic scene of the 2015 film, The Dressmaker, is to be understood in the context of abuse that the main character, Tilly, had been subjected to as a young girl. ${ }^{1}$ In what eventually proves to be an act of great injustice, Tilly is wrongly held responsible for the death of a young boy and sent away, causing both Tilly as well as her mother, who hovers on the brink of insanity, much anguish.

The film starts with Tilly, who has since become a famous dressmaker in Paris, returning to her home town to attend to her mother living as an outcast and hermit on the edge of the community, and also to face her traumatic past. She is shown throughout the film as seeking to make amends, employing her incredible talent as a dressmaker in order to transform the most ordinary woman into something extraordinary. When her attempts to reintegrate into the community fail, with her mother as well as her new found love Teddy, who had helped her remember what happened all those years ago, ${ }^{2}$ dying on top of everything else, Tilly resorts to revenge, burning the entire town down before walking away.

The Dressmaker's portrayal of revenge is quite disturbing. Perhaps because it is so very human to imagine the tables turned with one's enemies coming to a violent and definitive end. In this regard, McCullough (2008:10) writes how human beings, from an evolutionary perspective, from the earliest times have been wired for revenge, that is, how revenge can be considered to be very much part of what it means to be human. ${ }^{3}$

On the one hand, one could, and should, understand Tilly's grand act of destruction in terms of the years of torment and abuse that she had experienced from the townsfolk that continued even in the wake of her attempts to be reconciled back into the community. Tilly's actions thus can be said to come from a deep place of hurt. But nevertheless, to see the shocking act of revenge enacted with the whole town going up in flames raised for me, who considers myself to be a staunch pacifist, important questions regarding whether revenge is really inevitable? Is there not a way to deal with one's trauma that does not fall victim to the endless cycle of violence?

\section{The Dressmaker (2015). Written and Directed by Jocelyn Moorhouse.}

2.Mucci (2013:73) outlines the way in which childhood trauma might erase any trace of the event so that the survivor has a hard time in discerning what it is that she does or does not know.

3.McCullough (2008:48-61) explores from an evolutionary point of view of why human beings were adapted for revenge, i.e. what benefit there would be for them to engage in acts of revenge. To mention one such reason: revenge may serve as a deterrent for future violators as well as preventing perpetrators from repeating acts of aggression a second time. 
This question was with me as I recently worked on a commentary on Jeremiah for Paulist Press (Claassens forthcoming). The vivid depiction of revenge born out of severe trauma that is depicted in The Dressmaker is reminiscent of the virulent revenge poetry that is found in Jeremiah 46-51 known as the Oracles Against the Nations (OAN). In the second of three conclusions ${ }^{4}$ to the book of Jeremiah that through its expansive collection of poetic oracles interspersed with narrative has been seeking to come to terms with the greatly traumatic events of the Babylonian invasion and eventual exile between the years of 598 BCE and 587 BCE, one finds an extended revenge fantasy that pertains to all of Judah's neighbours who one after the other succumb to the violence of imperial forces sweeping through the country (Brueggemann 1998:419-420; O'Connor 2011:116-121). ${ }^{5}$ In the first part of the OAN, Judah's neighbours Philistia, Moab, Amnon, Damascus, Kedar, Elam and even Egypt all meet a similar fate to Judah as they all fall victim to the pervasive imperial domination of the Babylonian Empire. And in Jeremiah 50-51, the OAN reaches its climax with the spectacular downfall of the most revered enemy of all, the Babylonian Empire who throughout the book of Jeremiah has been responsible for incredible suffering by destroying the city, killing its inhabitants with the sword, and together with the famine and pestilence that followed in the wake of the invasion caused great hardship (Stulman 2005:349-352).

What makes this yearning for revenge all the more problematic in terms of a biblical text like Jeremiah is the fact that God is closely associated with this revenge fantasy when God is depicted as the Sovereign One who is ultimately responsible for the fall of the once powerful enemy. ${ }^{6}$ The fact that God is portrayed as the Mighty Warrior who has blood on his hands raises all kinds of questions regarding what we today, 500 years after the Reformation, as a community of believers who hold dear the principle of Sola Scriptura, do with such violent texts that revel in the downfall of the enemy and propagate revenge as a viable solution to the hurt and pain people are experiencing?

This question is particularly relevant given the deep wounds that many in this beautiful country of ours carry. Most of us would probably agree that 2016 has been quite a difficult year, particularly for those of us who find ourselves in Higher

4.The intensely complex book of Jeremiah that, in myriad ways seeks to explain comfort, pass judgment, and ultimately survive the trauma of the Babylonia invasion and exile, warrants an ending that does justice to the complexity that is invasiated with the arduous task of coming to terms with tha complexity that is associated with the arduous task of coming to terms with trauma. In this regard O'Connor has suggested that the book does not have just one ending but three separate endings (Jeremiah 45, 46-51 and 52). The literary form of the thre endings to Jeremiah in itself divulges the sheer impossibility of "reduc[ing] the disaster to one finale settled interpretation', and rather speaks in the three separate conclusions about the traumatic events in more than one mode of interpretation (O'Connor 2011:115-116).

5.A counter argument is to be found in Frechette (2016:78) who argues against the OAN being characterised as a revenge fantasy. Rather, he just sees this as a literary device that offers people a safe space to express their anger that might have distinct psychological and physical benefits.

6.In all of this display of revenge with the once powerful enemy coming to a fall, God is said to be the One with blood on his hands, the mighty warrior who decisively destroys the gods of the nations. One also sees this case for the sovereignty of God destroys the gods of the nations. One also sees this case for the sovereignty of God in the number of instances in which the gods of the nations are also sent into exile. For instance, in Jeremiah 48:7, Moab's god Chemosh is said to go into exile, togethe with his priests and attendance - a fate shared also by Amnon's god Milcom (49:3). This relates to the popular notion of the time that military defeat signals that the deity of the losing nation had lost the battle between the warring nations' gods. Judah's survival depended on whether they were able to regain confidence in God's ability and inclination to save (Stulman 2005:351)
Education. In a column that seeks to outline the sharp divisions that continue to exist in South Africa based on race, class, and I would also add sexual orientation, Max du Preez insightfully draws on the work of the Nicaraguan born American psychologist Martha Cabrera who has described her fellow Nicaraguans as 'multiple wounded, multiple traumatised', which according to Du Preez is an apt description of the current state of South Africans regardless of race, colour or creed (Du Preez 2016). This ongoing, unresolved trauma for Du Preez is the source of the eruption of the violent protests that we have seen this past year on university campuses across the country. Moreover, one could say that this deep sense of intergenerational trauma is responsible for the fact that we as a people are more divided than ever. These divisions are reflected in some profound expressions of Black pain we saw last year that have even resulted in statements that one could say propagate genocide (Stolley 2016), as well as in some overtly racist statements on social media that express an inability of some individuals to understand just how deeply, and adversely, centuries of colonial rule and decades of apartheid have impacted the economic development of black communities, particularly pertaining to the exclusion from tertiary education (Chutel 2016). And we who are gathered here today know all too well the very deep divisions that exist in the Dutch Reformed Church regarding the 2015 same-sex marriage decision followed by the even more painful 2016 follow-up synod (Steyn 2016). It is thus indeed a question of how we in 'a multiple wounded, multiple traumatised' community, church and country, and yes based on global events in 2016, also the world (Scherer 2016), must continue to live and work together in 2017. Particularly given that the very human reaction in response to being hurt or subjected to trauma for a long period of time is to retaliate in an act of revenge.

In this regard, it is important for us to contemplate whether the revenge poetry in the OAN as well as contemporary films like The Dressmaker do not open up our imagination to further strengthen our vengeful inclinations, giving us permission to go about wishing and hoping and even praying for our enemies to fall? And probably the most disturbing question of all, considering God's involvement in the OAN: do biblical texts such as the OAN instigate further violence by suggesting that believers act as God's agents of destruction to help along the process? As Seibert (2012:10) has rightly observed, the problem is not violent texts but their violent readers.

I propose that it is precisely revenge fantasies such as are found in the OAN in Jeremiah that underscore the necessity for responsible Bible reading practices. I argue that in order to protect us from our own worst selves, the very human tendency to resort to revenge that inevitably leads to violence, one needs to read these biblical texts in terms of contemporary hermeneutical approaches that may play some role in helping bring an end to violence.

\section{Virtual therapy}

A first such approach that serves as an important tool to help us understand these revenge fantasies as found in the 
OAN is the relatively new field of inquiry of trauma hermeneutics. Similar to understanding Tilly's act of revenge against the backdrop of years of abuse as a small child, when viewed through a hermeneutical lens of trauma, the revenge fantasies contained in the OAN exhibit an important rhetorical function, constituting a vital aspect of the process of recovery from the extreme trauma that the people of Judah had lived through (O'Connor 2011:116-121; Stulman 2005:383-384). A recent news story shows how survivors from the war in Iraq and Afghanistan are actually helped to recover from post traumatic stress disorder (PTSD) by playing violent video games under the guidance of trained trauma counsellors (Halpern 2008). By engaging in a virtual display of the terrifying violence associated with war, these former soldiers are helped to express their emotions and feelings regarding what they are reliving in what can be described as a controlled environment. ${ }^{7}$ The virtual reality these former soldiers are entering offers a way to deal with the traumatic memories that have a tendency to haunt survivors and prevent them from reconnecting with life (O'Connor 2011:24-25).

In a similar fashion, the exceedingly violent portrayal in the OAN may be offering the survivors of the Babylonian invasion and exile a way to face their traumatic past by putting into words what had happen, to break through denial and also to desensitise survivors in a safe space by reacting to the violence they had lived through (O'Connor 2011:3-4). In this regard, trauma theorists point to the important role of literature that seeks to represent trauma that serves as a means of coming to terms what has happened, making some sort of sense of it, which is a crucial step on the road to recovery (Mucci 2013:119-120). As Stulman (2013) poignantly writes regarding Jeremiah as literature that emerged out of disaster:

Perhaps the only thing to combat despair, especially among the powerless is speech - often in artistic expression. Perhaps the only thing to survive the violence of empire is the violence of poetry, testimony, and liturgy. (p. 70)

One should further note that the OAN that are directed to Judah's neighbours and in particular Judah's enemy in the form of the Babylonian empire, which receives a full two chapters, is very much expressing an act of wishful thinking. The mere thought of imagining an end to the brutal empire and the state sponsored violence that had wrecked their lives hence serves as a crucial means of survival (Stulman 2005:386). So we read in Jeremiah 51:48 how the heavens and earth, and all that is in them, will shout for joy over the destruction of Babylon - a sentiment quite similar to Nahum 3:19 in which the people of Judah are shown to be joyously clapping their hands over the dead bodies of their enemies (Claassens 2016:341; O'Brien 2010:125).

7.Cf. Frechette's (2016:76) interpretation of the Old Testament as a controlled environment that creates a safe space for people to voice their pent-up anger and
rage. Cf. also Stulman (2005:384-385) who sees the OAN as a liturgical space where rage. Cf. also Stulman (2005:384-385) who sees the OAN as
the exiles are able to re-imagine and reframe social reality.
However, even though interpretative approaches such as trauma hermeneutics help one to make sense of the violent rhetoric found in the revenge fantasies of the OAN, one also has to face the reality, as O'Connor (2011:119-120) has argued, that 'hatred and violence live in the oracular world because they remain alive among survivors'. There is thus a real danger that these expressions of violence may stay alive and grow ever stronger with each utterance until the violent ideas they propagate are considered to be normal.

One should further keep in mind that in terms of the example of The Dressmaker, this narrative portrayal of revenge in the OAN should not serve as a blueprint for our time, inciting other victims of violence to act accordingly. Given the very high cost of revenge (McCullough 2008:25-40), there must be another way. It is in the interest of us all to explore strategies that help us move beyond revenge.

In this regard, there are many scholars who adhere to what Fiorenza (1988:3-17) has already mentioned in her 1987 Society of Biblical Literature Presidential address, that is, the ethical obligation to read otherwise, to become 'resistant readers' of particularly those texts that can do harm in the hands of uncritical, fundamentalist Bible readers. ${ }^{8}$

\section{The ethical obligation to read otherwise}

In the first instance, feminist biblical interpretation is an important tool that is used to resist the violent aspects of biblical texts such as in the OAN in Jeremiah. I find quite helpful Sharp's (2017) definition of feminist biblical interpretation that she describes as follows:

1. to honour all subjects

2. to interrogate power relations

3. to reconstitute community.

In terms of a biblical text like Jeremiah, this implies that one seeks to pay attention to the bodies of women and other silenced and marginalised entities in the text that quite often are bodies in pain. The objective of honouring all subjects implies furthermore that one considers all voices reflected in the biblical text - explicit, but quite often muted or channelled through the dominant viewpoint of the writers or editors of the book. This implies too, as Sharp (2013a:44) says it so well, 'to hear the stories of others - to hear what is at stake for the Other'.

Such an approach moreover implies that one is mindful of the harmful effects of power in the text and in its interpretations, and deliberately seeks ways to challenge the ideologies and worldviews that give rise to such instances in which power is abused (Sharp 2013a:43). In terms of Jeremiah, such a gender-critical reading would be attentive to, for instance, the ways in which female imagery and gender stereotypes are utilised by the male authors of the book in 8.See also Seibert (2012:66-67) who argues that readers have the ethical obligation to read the Bible, and particular those texts that can be considered harmful, critically. 
order 'to promote the male discourse on war and destruction, theologized as judgment' (Bauer 2003:161). ${ }^{9}$

Feminist biblical interpretation also seeks to move beyond only critiquing the harmful ideologies and gendered constructions embedded in the text. In terms of Sharp's third objective, it is vital for feminist interpreters to reconstitute community, to work for justice and peace that requires the reader to 'dare to read resistantly, creatively, and constructively with and for communities of readers who privilege the voices and experiences of the marginalized' (Sharp 2013a:43; see also Sharp 2013b:172). Such a courageous act of reading the text otherwise is related to our collective, ongoing attempts to change oppressive paradigms today and is deeply rooted in the feminist concern of cultivating a new vision of the world in which prejudice, hatred and the abuse of power has no place.

In terms of the OAN, feminist biblical interpretation implies that one ought to be troubled by the way in which the cities of Judah's neighbours, like Jerusalem herself, are imaged in female terms and in an act of warfare, humiliated and shamed by military invasion. This is evident in terms of 'sheltered daughter Egypt' whose enemies shall attack her with axes (46:22) and who will be humiliated by her enemies (46:24), as well as the female, sexualised, animalistic imagery that is used in order to express the degradation experienced by Daughter Babylon (50:11-12). ${ }^{10}$

Also in terms of The Dressmaker, a feminist reading strategy may yield some significant results. So one conceivably could speak of Tilly's act of revenge at the end of the film in terms of female agency that does succeed in transcending the gendered stereotype of the helpful female victim, thereby representing women as agents of anger and aggression. ${ }^{11}$ However, as Hesford (1999:200) points out, this association with violence means that one still for the most part remains trapped within the binary opposition that equates male with powerful and female with being powerless. Even if one were to reverse this binary, one still remains within the confines of patriarchal ideologies and essentialised notions of gender. As Hesford (1999:202) writes, 'what is mastered in the fantasy is the master's language'.

A second approach that is quite helpful in reading the OAN and its portrayal of revenge in our complex geopolitical world is postcolonial biblical interpretation that, as Maier (2013b:133) describes it well, analyses 'the power structures,

\footnotetext{
9.See also the rhetorical strategies Bauer (2003:161) identifies in terms of a gendered reading of Jeremiah that includes 'male fear of female sexuality, fear of loss of control over possessions/wives, fantasies of sexualized violence with the stated intention of making the male audience turn around/repent'.

10.See also the image in Jeremiah 51:33 of Daughter Babylon being a threshing floor that is being trodden in order to communicate something of the violent treatment to which this female personification of Babylon is subjected.

11. Hesford (1999:192) writes that a revenge fantasy is a good example of how women might either 'negotiate, resist or reproduce rape scripts with their bodies, actions might either' 'no the ren and narratives. On the one hand, revenge fantasies might be considered valuable in the sense that that they may render 'bodily pain and trauma tellable' that may help the survivor to 'undo the gocia dimension of the self lost in the midst of violation. However, on the other hand, revenge fantasies may actually perpetuate rape scripts such as that women are rapable.
}

oppressive attitudes, and effects of imperialist regimes' on individuals and communities.

In terms of the literature that emerged from this period before, during and in the aftermath of the Babylonian invasion and exile, one sees how a group of Judean survivors struggled to reclaim their identity after the devastating display of imperial force (Davidson 2013:162; O'Connor 2011:93-94). ${ }^{12}$ The book of Jeremiah hence constitutes a complex mix of the reality and effects of imperial domination by the hand of the Babylonian war machine, while also showing signs of a counter imperial reality in which those living in the shadow of the empire found creative avenues for surviving imperial rule. Postcolonial criticism thus inquires how ordinary people, Spivak's 'subaltern' (1988:271-313) whose voices are muted under imperial rule, survive. For instance, Sharp (2013a:45) shows how colonised subjects employ a variety of survival strategies 'to resist the colonizing distortions, commodifications, and threatened erasure of their indigenous culture and the deformation of their own subjectivity and agency ${ }^{\prime}{ }^{13}$

Especially important for reading the revenge fantasy outlined in the OAN is the question of how the 'Other' is construed by those in power. McKinlay (2013:22) maintains that the postcolonial interpreter is sensitive to the use of power in how others are defined or represented, and moreover what the purpose of such portrayals would be in terms of justifying control of the other (Segovia 2006:38). In particular, Sharp (2013b:152) contends that the 'virulent language of military despoliation and the sexual shaming of enemies' that runs throughout the OAN is a form of 'cultural violence' that must be named and rejected in the strongest of terms. At present, it is more important than ever to move away from language that is rooted in the act of shaming, rejection, or in the most extreme instances, extermination of the other - even the other who in our mind has caused us great harm (Sharp 2013b:153, 155).

Therefore, both feminist and postcolonial biblical interpretations are important tools in the ongoing process of cultivating responsible Bible reading practices that have significant decolonising and depatriarchalising effects in our world today that challenge injustices, interrogate power relations and in the process, in some small way, enhance the lives of those individuals who have been adversely affected by patriarchy, heteronormativity, as well as imperial rule (McKinlay 2013:36; Sharp 2013a:47).

\footnotetext{
12.See also Steed Davidson's extensive analysis on a postcolonial reading of Jeremiah Davidson (2011) argues that the book of Jeremiah stands as a text of resistance to imperial power. As a book written, compiled, and edited in imperial contexts, it reflects the reality of empire. At the same time, as a text written by the dominated, it offers avenues of resistance (pp. 3-4). In particular, we see how this book reflects the 'survival mechanisms of the people to preserve and (re)shape their identity in the face of the loss of the land'. Also, Maier (2013b:143) considers the effects of Empire on the people of Judah as reflected in Jeremiah in a recent article that seeks to develop a postcolonial reading of Jeremiah 21:1-10, arguing that 'Jeremiah to develop a postcolonial reading of Jeremiah 21.1-10, arguing that Jeremiah 21:1-10 formulates a strategy of those who survived the Babylonian conquest of Jerusalem to legitimate both their own survival and their submission to Babylonian

13.Among the strategies that colonised subjects may employ are the 'tactics of assimilation, mimicry, parody, and strategic silence as well as outright resistance' (Sharp 2013a:45).
} 
But despite the important contribution these hermeneutical approaches make toward cultivating responsible Bible reading practices that are vital for nurturing ethical, just communities that actively pursue justice, even these hermeneutical approaches may not be enough for the troubling times we are facing. We need something more, something truly counterintuitive, and one could perhaps even say, extraordinary. In the concluding part of this article, I would like to mention two possible lines of inquiry that can be characterised as extraordinary reading strategies for the extraordinary times in which we are living.

\section{Extraordinary reading strategies}

The first such reading strategy regards the inclination of reading against the grain of the dominant trajectory of violence and vengeance such as also reflected in the OAN in a manner that does not succumb to the very human inclination of revelling in the demise of the other, regardless of the harm this particular enemy had caused. Actually in his book, Beyond Revenge, McCullough (2008:13-14) notes that it is not just revenge that forms an integral part of human nature, but from an evolutionary perspective, forgiveness can also be considered to be part of our DNA. McCullough (2008:124130) explores some reasons why it would have been considered beneficial to forgive those who have done one harm. Aside from the proven health benefits associated with not holding on to a grudge, forgiveness also from the earliest times has been associated with the necessity of cooperation that could be said to be vital for survival. Our earliest ancestors understood all too well that we need each other if we are going to survive.

A central condition for people to transcend their natural inclination for revenge and enact forgiveness is to be able to once more see the human behind the violation. I find it quite interesting that within the OAN in Jeremiah 46-51 there are moments in which one receives a glimpse of the humanity of Judah's enemies, and most surprisingly of all, even of the Babylonian empire. For instance, in Jeremiah 51:8 one sees a surprising desire for the healing of Babylon, with the speaker calling for balm to be brought so that Daughter Babylon may be healed. In Jeremiah 51:9, the speaker once again expresses that he tried his best to heal Babylon, but to no avail. 'She could not be healed'. Also in Jeremiah 50:45 the enemy who is falling victim to violence is described with a term of empathy, 'the little ones of the flock' that shows some signs of resisting the dehumanisation of the other even as one is recovering from some serious experiences of dehumanisation oneself. Moreover, one of the most touching images in the OAN is God's command in Jeremiah 49:11 to the Ammonites to leave their orphans behind, for Godself is said to keep them alive. ${ }^{14}$ It seems that the image of God caring for the widows and orphans extends also to Judah's neighbours when the Ammonite widows profess to trust in God (Stulman 2005:369).

14.Brueggemann (1998:457) calls this reference to God caring for the orphans of the Ammonites an 'odd footnote'. In a society devastated by war, there will inevitably be orphans and widows without resources and protection; however, Jeremiah be orphans and widows without resources and protection; however, Jeremiah
$49: 11$ makes the powerful claim that these most vulnerable human beings will be 49:11 makes the
safe with God.
These examples from the OAN that exhibit glimmers of an alternative understanding that extends beyond the boundaries of us and them is rooted in an understanding of a shared vulnerability. In her work dedicated to cultivating a more compassionate society, Nussbaum (2013:3) speaks about the importance of recognising a common humanity, a shared vulnerability among people that transcend boundaries such as gender, race, class and sexual orientation. It is to truly see the face of the other; to imagine another's feelings, fears, joys, hopes and frustrations that form the basis of any attempt to move beyond revenge. This is not always easy - it seems to be easier these days to build walls rather than bridges. But I would propose that we today are in desperate need of bridge builders and boundary crossers - individuals who are able to stand in the gap and bring people together to make a common future possible. ${ }^{15}$

A second thought I would like to consider regards the question of what it is that makes forgiveness possible? Towards the very end of 2016, I saw another film that also deals with trauma and the response to trauma but that offers quite a striking alternative to The Dressmaker's descent into revenge. In the cinematic sequel to the Harry Potter saga, Fantastic Beasts and Where to Find Them ${ }^{16}$ constitutes a rather ingenious portrayal of one of the textbooks that the students at Hogwarts studied, and specifically the back story to this textbook that outlines the author's adventures in the United States that led him to write this particular textbook.

The film with its fascination with fantastic beasts, which harbours sub-tones of the current ecology crisis and propagates the appreciation and preservation of wild animals, is set in New York that has been plagued by terror the subtext of $9 / 11$ being quite evident in terms of the images of a World Trade Centre-like building being demolished at one point in the film.

At the very end of Fantastic Beasts and Where to Find Them, after the forces of the dark wizard had been destroyed, the witches and wizards are faced with the question of just how to deal with the terrible effects on the city and its inhabitants that had been terrorised by the violent destruction enacted by the villain. Typically the memory of No-majs (non-magicians or Muggles in the prior books) is obliterated in order that they might forget everything that has to do with magic. However, in this instance, it is not possible as too many people have seen the destruction which means that one cannot obliterate everyone's memory. In response to this dilemma, the hero of the story, the fantastic beast whisperer, Newt Scamander, releases one of his fantastic beasts - a great big eagle who possesses the gift of amnesia. As the giant eagle flies over the city, a soft wind blows, helping the people to forget the trauma they had experienced. And as they are

15.Nussbaum (2013) argues that it is often people's natural tendency to protect the fragile self by denigrating and subordinating others'. However, she argues that
even when a society has avoided falling into that trap, these forces lurk in society even when a society has avoided falling into that trap, these forces lurk in society
and need to be counteracted energetically by an education that cultivates the and need to be counteracted energetically by an education that cultivates the
ability to see full and equal humanity in another person, perhaps one of humanity's ability to see full and equal humanity in another
most difficult and fragile achievements (p. 3 ).

16.Fantastic Beasts and Where to Find Them (2016). Written by JK Rowling. Directed by David Yates. 
forgetting, the city miraculously heals itself with demolished buildings restored to their former glory.

In his interesting article on 'Historical Injustice and the Art of Forgetting', Vosloo (2014:76-77) offers a number of reasons why such an art of forgetting can be associated with healing. In addition 'to the fact that too much memory of the past will make life unbearable, and that it will have an unhealthy impact on our life and happiness', to relive the traumatic memories of the past may actually lead to further acts of violence that may be the source of further injustice. Vosloo (2014:77) cites Volf (2006) who says the following:

Victims will often become perpetrators on account of their memories. It is because they remember past victimization that they feel justified in committing present violence ... So easily does the protective shield of memory morph into the sword of violence. (pp. 32-33)

Also Smit (1996) writes on the Christian imperative to forget that is found alongside the call not to forget. He writes that:

forgetting can also be a moral activity. The wonder of the message of the gospel for Christians is precisely that God removes our sins from us as far as the east is removed from the west and never thinks of them. ${ }^{17}$ (p. 116)

Now one should immediately say that it can be quite dangerous to make a case for the art of amnesia - especially in a time where many people in South Africa have not even faced up to the hurts of the past. ${ }^{18}$ This is surely not a case for denying justice or our role in it. But what it may suggest is that in order not to fall into the perpetual cycle of violence where The Dressmaker option is the only logical conclusion, at some point one needs to come to a point where one forgets the hurt of the past to move on to a restored community. In this regard, Gobodo-Madikizela (2014) writes that:

South Africans face the challenge of how to embrace the past without being swallowed by the tide of vengeful thinking ... if memory is kept alive to cultivate old hatreds and resentments, it is likely to culminate in vengeance, and in a repetition of violence. But if memory is kept alive in order to transcend hateful emotions, then remembering can be healing. (p. 103)

At the same time, it is vital to also say that this act of forgetting cannot and should not occur if the injustice persists. GobodoMadikizela warns that forgiveness and reconciliation cannot be separated from transformative change that addresses the historical injustices of the past. ${ }^{19}$

In the OAN it is quite interesting that in the very last chapter of Jeremiah, in the third of the three conclusions with which the book of Jeremiah ends, one finds a remarkable story that suggests something of this art of forgetting. After the

17.See also the striking reference in Jeremiah $31: 24$ where God says: 9 will forgive their wickedness and will remember their sins no more' (Vosloo 2014:78).

18.Vosloo (2014:78) also warns against the dangers of forgetting, writing that to fail to remember e.g. 'the horror of the Holocaust or the brutality of apartheid, the language of forgetting seems to be irresponsible and dangerous'.

19.See also Vosloo (2016)'s insightful article that brings the work of Pumla GobodoMadikizela into conversation with Paul Ricoeur in reflecting 'on dealing with the past, mutual recognition, and embodied performativity'. elaborate revenge poetry that revels in the downfall of Babylon especially in Jeremiah 50-51, in Jeremiah 52, one finds a very matter of fact restatement of the facts associated with the reality of the Babylonian invasion and exile. It happened. No denying. But then in the final scene of the book, one finds the miraculous, probably imaginary, description of King Jehoiachin's survival; how he after 37 years in Babylon not only has survived but is receiving special treatment with King Evil-Merodach showing him favour, speaking kindly to him, being given a seat of honour, receiving a daily allowance, and for the rest of his life, regularly dining at the king's table (52:31-34). ${ }^{20}$

One cannot help but wonder what that dinnertime conversation looked like. Probably they were not talking about everything that had happened in the painful past. This fanciful image that quite likely transcends historical truth fulfils an important rhetorical function. Poser (2016:44), citing the work of trauma theorist Dori Laub, argues that the imaginative elements of trauma narratives contain in themselves the secret of survival as it serves as an act of resistance against the threat of extermination. The surprising image of enemy kings eating together serves as a poignant symbol of survival, asserting that perhaps the Judean people, as also the Judean king in exile, and also the prophetic word as captured in the book of Jeremiah will survive. This image of restoration is not void of complexity though - the king and his people still find themselves in exile in the grips of the empire's power. And yet, this rather incredible account serves as another act of wishful thinking, but one that does not imagine the enemy coming to a violent end as in the OAN, but one that speaks of perpetrator and victim eating together. This final image in a book dominated by violence and vengeance thus might be said to conjure up a counter reality where revenge is not the only option.

\section{Conclusion}

In the conclusion of his book, Beyond Revenge, McCullough (2008:224-225) writes that in light of the fact that both revenge and forgiveness can be described as integral to the human condition, that humans in terms of the Latin terminology that is typically used to classify species can be said to be both Homo ultor and Homo ignoscens. But as he also notes, we humans are also Homo sapiens, which is derived from the Latin term for 'the knower' or the 'wise'. Thus, even though we as humans have the ability to both engage in 'vengeful aggression to protect ourselves, [and] our loved ones', as well as at times to be 'willing to put resentment and ill will behind us':

evolution also has made us Homo sapiens that implies that we have discovered many of the secrets of how to help Homo sapiens display more of its forgiveness and less of its violence. (McCullough 2008:237)

20.Brueggemann (1998:493-494) writes how this final paragraph is chronologically removed from the preceding narrative. So Jeremiah $52: 30$ is dated to $582 \mathrm{BCE}$ removed from the preding narrative. So Jeremiah $52: 30$ is dated to 582 BCE, while Jeremiah 52:31 suddenly jumps to 561 BCE. King Jehoiachin who was exiled in 598 BCE is alive and well after 37 years in exile. And while still finding himself in captivity, he is nevertheless recognised as king with the new Emperor speaking kindly to him, and treating him with dignity. The story of the boy king who has grown old in exile is told in the concluding chapter to Jeremiah in order to communicate the powerful message that God is the faithful God who keeps promises. 
This article is dedicated to Prof. Yolanda Dreyer who throughout the years has been for me, as well as others, a model of Homo Sapiens as outlined above. With great wisdom and empathy and resolve, Prof. Dreyer was indeed a trailblazer in terms of women in the Church and women in Theological Education. I remember one such instance of her great wisdom that she shared with a group of female theological students more than 20 years ago. At the time I was a very young theological student who was struggling how to navigate the treacherous waters of a largely male-dominated theological faculty and church. Prof Dreyer shared some different options with us for taking down the seemingly insurmountable wall of patriarchy that has, and to some extent, continues to do much harm in our churches and our universities. She noted that there is the 'bulldozer' way of women who run themselves right into the wall, inflicting great wounds on their bodies and psyches with the wall not moving an inch. But then there is the 'ant' option, with various women and men in different times and places calving out sand underneath this great wall, slowly but surely causing the wall to become vulnerable. And then one day, with one of the 'bulldozer' representatives, the wall may come down.

These words so many years ago stayed with me as I studied and taught in the United States, returning to my alma mater in 2010. We have come a long way since Prof. Dreyer told this story to a group of theological students in 1996. There are now at our various theological institutions and denominations many more female lecturers, female pastors and female students. But we also know, as highlighted in this article, that there is still much to do. In the spirit of Prof Yolanda Dreyer's example throughout the years, we are called to help people read the Bible otherwise; to pay attention to the marginalised voices in the text and the world. We are called to resist stereotypes and the use of derogatory language for those who differ from us. We are called to resist injustice and to do everything possible to challenge the explicit and implicit manifestations of racism, sexism, and homophobia that will continue to haunt us if we continue to ignore the pain of those who are suffering. As the saying goes: 'Justice delayed is justice denied'. And finally, we are called to help foster communities of care, rooted in kindness, compassion and empathy that are committed to breaking down walls rather than erecting them.

\section{Acknowledgements Competing interests}

The author declares that she has no financial or personal relationships which may have inappropriately influenced her in writing this article.

\section{References}

Bauer, A., 2003, Gender in Jeremiah: A feminist-literary reading studies in biblical literature 5, Peter Lang Inc., New York.

Brueggemann, W., 1998, A commentary on Jeremiah: Exile and homecoming Eerdmans, Grand Rapids, MI.

Chutel, L., 2016, 'South Africans just can't hide their racism on social media', Quartz Africa, viewed 01 February 2017, from https://qz.com/867927/social-media rants-reveal-the-enduring-racism-of-post-apartheid-south-africa/
Claassens, L.J., 2016, 'God and violence in the prophets', in C. Sharp (ed.), Oxford handbook of the prophets, pp. 334-352, Oxford University Press, Oxford.

Claassens, L.J., forthcoming, 'Jeremiah', in J. Aguilar, R. Clifford \& D. Harrington et al. (eds.), The Paulist Bible commentary, Paulist, New York.

Davidson, S.V., 2011, Empire and exile: Postcolonial readings of the Book of Jeremiah, LHBOTS 542., Bloomsbury T\&T Clark International, London.

Davidson, S.V., 2013, "Exoticizing the Otter," The curious case of the Rechabites in Jeremiah 35', in C.M. Maier \& C.J. Sharp (eds.), Prophecy and power: Jeremiah in feminist and postcolonial perspective, pp. 189-207, Bloomsbury T\&T Clark, London.

Dempsey, C.J., 2007, Jeremiah: Preacher of grace, Poet of truth, Liturgical Press, MN.

Diamond, A.R. \& Stulman, L. (eds.), 2011, Jeremiah (Dis)Placed: New directions in writing/reading Jeremiah, Bloomsbury T\&T Clark, London.

du Preez, M., 2016, 'Who is to blame for South Africa's failures', News24.com, viewed 01 February 2017, from http://www.news24.com/Columnists/MaxduPreez/whois-to-blame-for-south-africas-failures-20160614

Fiorenza, E.S., 1988, 'The ethics of biblical interpretation: Decentering biblical scholarship', Journal of Biblical Literature 107(1), 3-17. https://doi. org $/ 10.2307 / 3267820$

Frechette, C.G., 2016, 'Daughter Babylon Raped and Bereaved (Isaiah 47): Symbolic violence and meaning-making in recovery from Trauma', in E. Boase \& C.G.A Frechette (eds.), Bible through the Lens of Trauma, pp. 67-83, Semeia Studies, 86, SBL Press, Atlanta, GA.

Gobodo-Madikizela, P., 2014, Dare we hope? Facing our past to find a new future, Tafelberg, Cape Town.

Halpern, S., 2008, 'Virtual Iraq: Using simulation to treat a new generation of traumatized veterans', The New Yorker, viewed 01 February 2017, from http:// www.newyorker.com/magazine/2008/05/19/virtual-iraq

Hesford, W.S., 1999, 'Reading rape stories: Material rhetoric and the trauma of representation', College English 62(2), 192-221. https://doi.org/10.2307/379018

Maier, C.M., 2013a, 'After the "One-Man Show": Multi-authored and multi-voiced commentary writing', in C.M. Maier \& C.J. Sharp (eds.), Prophecy and power: Jeremiah in feminist and postcolonial perspective, pp. 72-85, Bloomsbury T\&T Clark, London.

Maier, C.M., 2013b, 'God's cruelty and Jeremiah's Treason: Jeremiah 21:1-10 in postcolonial perspective', in C.M. Maier \& C.J. Sharp (eds.), Prophecy and power: Jeremiah in feminist and postcolonial perspective, pp. 133-149, Bloomsbury T\&T Clark, London.

Maier, C.M. \& Sharp, C.J. (eds.), 2013, Prophecy and power: Jeremiah in feminist and postcolonial perspective, Bloomsbury T\&T Clark, London.

McCullough, M.E., 2008, Beyond revenge: The evolution of the forgiveness instinct, Jossey Bass, San Francisco, CA.

McKinlay, J., 2013, 'Challenges and opportunities for feminist and postcolonial biblical criticism', in C.M. Maier \& C.J. Sharp (eds.), Prophecy and power: Jeremiah in feminist and postcolonial perspective, pp. 19-37, Bloomsbury T\&T Clark, London.

Mucci, C., 2013, Beyond individual and collective trauma: Intergenerational transmission, Psychoanalytic treatment, and the dynamics of forgiveness, Karnac Books, London.

Nussbaum, M.C., 2012, The new religious intolerance: Overcoming the politics of fear in an anxious age, Bellknap Press, MA.

Nussbaum, M.C., 2013, Political emotions: Why love matters for justice, Harvard University Press, Cambridge, MA.

O'Brien, J.M., 2010, 'Violent pictures, violent cultures? The "Aesthetics of Violence" in contemporary film and in ancient prophetic texts', in C. Franke \& J.M. O'Brien (eds.), Aesthetics of violence in the prophets, pp. 112-130, T \& T Clark, Sheffield.

O'Connor, K.M., 2007, 'Rekindling life, igniting hope', Journal for Preachers 30(2), 30-34.

O'Connor, K.M., 2011, Jeremiah: Pain and promise, Fortress Press, MN.

Poser, R., 2016, 'No words: The book of Ezekiel as trauma literature and a response to exile', in E. Boase \& C.G. Frechette (eds.), Bible through the lens of trauma, pp. 27-48, Semeia Studies, 86, SBL Press, Atlanta, GA.

Rizzo, A., Pair, J., McNerney, P.J., Eastlund, E., Manson, B., Gratch, J. et al., 2005, 'Development of a VR therapy application for Iraq war military personnel with PTSD', Studies in Health Technology and Informatics 111, 407-413.

Scherer, M., 2016, '2016 Person of the year: President of the divided States of America', Time, viewed 01 February 2017, from http://time.com/time-person-ofthe-year-2016-donald-trump/

Segovia, F.F., 2006, 'Biblical criticism and postcolonial studies: Toward a postcolonial optic', in R.S. Sugirtharajah (ed.), The postcolonial biblical reader, pp. 33-44 Blackwell Publishing, MA

Seibert, E., 2012, The violence of scripture: Overcoming the Old Testament's troubling legacy, Fortress Press, Minneapolis, MN.

Sharp, C.J., 2013a, 'Mapping Jeremiah as/in a feminist landscape: Negotiating ancient and contemporary terrains', in C.M. Maier \& C.J. Sharp (eds.), Prophecy and power: Jeremiah in feminist and postcolonial perspective, pp. 38-56, Bloomsbury T\&T Clark, London.

Sharp, C.J., 2013b, 'Buying land in the text of Jeremiah: Feminist commentary, the Kristevan Abject, and Jeremiah 32', in C.M. Maier \& C.J. Sharp (eds.), Prophecy and power: Jeremiah in feminist and postcolonial perspective, pp. 150-172 Bloomsbury T\&T Clark, London.

Sharp, C.J., 2017, 'Is this Naomi? A feminist reading of the ambiguity of Naomi in the Book of Ruth', in L.J. Claassens \& C.J. Sharp (eds.), Feminist frameworks: Celebrating intersectionality, interrogating power, embracing ambiguity, Bloomsbury T\&T Clark, London. 
Smit, D., 1996, 'Confession-guilt-truth-and-forgiveness in the Christian Tradition', in H.R. Botman \& R.M. Peterson (eds.), To remember and to heal: Theological and psychological reflections
Rousseau, Cape Town.

Spivak, G.C., 1988, 'Can the subaltern speak?', in C. Nelson \& L. Grossberg (eds.), Marxism and the interpretation of culture, pp. 271-313, University of Illinois Press, Chicago, IL.

Steyn, P., 2016, NG Kerk besluit wéér teen gays, Netwerk24, viewed 01 February 2017 from http://www.netwerk24.com/Nuus/Algemeen/ng-kerk-besluit-weer-teengays-20161110

Stolley, G., 2016, Malema not calling for the slaughter of whites, for now, IOL, viewed 01 February 2017, from http://www.iol.co.za/news/crime-courts/malema-notcalling-for-the-slaughter-of-whites-for-now-2087713

Stulman, L., 2005, Jeremiah, Abingdon Press, Nashville, TN.
Stulman, L., 2013, 'Reflections of writing/reading war and hegemony in Jeremiah and in Contemporary U.S. Foreign Policy', in C.M. Maier \& C.J. Sharp (eds.), Prophecy and power: Jeremiah in feminist and postcolonial perspective, pp. 57-71, Bloomsbury T\&T Clark, London.

Volf, M., 2006, The end of memory: Remembering rightly in a violent world, Eerdmans, Grand Rapids, MI.

Vosloo, R., 2014, 'On historical injustice and the art of forgetting', Oral History Journal of South Africa 2(2), 72-84.

Vosloo, R., 2016, 'Touch gives rise to thought: Paul Ricoeur and Pumla GobodoMadikizela on dealing with the past, mutual recognition, and embodied performativity', paper presented at the 10th Annual Society for Ricoeur Studies Conference, Crossing Boundaries: Ricoeur in a Global Age, De Paul University, Chicago, 6-9th October. 